\title{
Water Users' Associations : Impact of The Farm Location on Salted land at Sharkia Governorate
}

\author{
Prof. Ali Ahmed Ibrahim Dr. Hadil Taher Hassanain \\ Dept. of Agricultural Economics, Faculty of Agriculture, Zagazig University, Egypt.
}

\begin{abstract}
In Egypt, Nile is the main conventional source of fresh water stored in the Lake Nasser to meet needs with Egypt's annual share of water, which is currently at 55, 5 billion cubic meters, Rainfall is rare and the desert covers most of the country area, except for a narrow strip of cultivated land and urban areas along the Nile river course. In addition, quota of Egypt from the Nile River, which represents the main source of water of the country, hasn't changed since 1959. Water is subject to certain standards, controls and issues of equitable distribution of dwindling water supplies are becoming more serious, where there is excess use of water at the beginnings of the canals or obvious lack of water supply at the ends, leading to decreased productivity for the main cultivated crops, and this led to damage productivity of cultivated lands .So this study is concentrated on the establishment of water users associations is justified by the participatory approach in water management to allow farmers to concentrate efficiently their efforts and means for joint actions aimed at the optimum utilization of water resources on irrigated and reclaimed lands as well as it is focused also on the impact of the site in distribution of water along the Masqa and reduce differences in water size distributed, so the main objectives can be summarized in measuring the impact of the farm site on masqa at the optimum productivity levels and maximizing profit of wheat producers , Estimate the farm income loss and net profit loss for wheat producers due to the lack of optimum use of resources and access to level of profit maximization of agricultural inputs. To accomplish the previous objectives a questionnaire sheets has been designed to collect and conduct a suitable primary field data applied on a random intentional sample in Sharkia governorate in Faqous and Abou-Hamad because the majority of water links exist in these two centers .It has been selected three villages in AbouHmad (the Almazemih - Manshiet Saeed - Abu Hagar). It has been selected in Faqous (Alrawda - Ibn Amr) because they are the largest area wherehave been carried out irrigation project development. In addition wheat farmers has been selected randomly through a personal interview during the period from January to March in 2015.
\end{abstract}

\section{Introduction:}

In Egypt, water resources are limited to the Nile River, deep ground water in the Delta, the Western Deserts and Sinai, rainfall and flash floods. Nile is the main conventional source of fresh water stored in the Lake Nasser to meet needs with Egypt's annual share of water, which is currently at 55, 5 billion cubic meters. Egypt receives $98 \%$ of its fresh water resources from outside its international borders. The Nile is shared by 9 other African countries and an estimated 460 million people depend on it, which is expected to double within the next 25 years, thus making an 
agreement on the sharing of water resources a sensitive matter .Non-conventional water resources include agricultural drainage water, desalinized brackish groundwater and or seawater, and treated municipal waste water. Desalination of water has been given low priority due to this high costs.

Water requirements are continuously increasing due to population increase and improving standards of living, as well as the governmental policy to reclaim more lands and encourage industrialization. Agriculture is the largest component of the water demand in Egypt, as it consumes more than 85\% of Egypt's share of Nile water annually. Municipal and industrial requirements represent a smaller portion of Egypt's total water requirements. Water supply and sanitation is managed by the Ministry of Housing, Utilities and new Communities.(MHUNC). The Ministry of Water resources and Irrigation MWRI) is responsible for ensuring water of an acceptable quality for the water treatments plants.

Egyptian government has established in the last period "Water Users' Associations" (WUA), that (registered under irrigation and drainage ( Act No. 12of 1994), its aimed to develop the participatory irrigation management concept for increasing water use efficiency, through the involvement of all stakeholders, as much as possible, in the various management activities. WUA consists of a group of farmers, all served by a common source of water, who join together to allocate, distribute, and manage water and allows farmers to perform activities that are more difficult or impossible to do individually.

\section{Main problems:}

Water is one of the most important inputs for economic development. Size, type, and location of the economic activities depend on the nature, quantity, and quality and location of the available water resources. The less the water resources are and the more the demand is, the more important water is. This is the case in Egypt, where rainfall is rare and the desert covers most of the country area, except for a narrow strip of cultivated land and urban areas along the Nile river course. In addition, quota of Egypt from the Nile River, which represents the main source of water of the country, hasn't changed since 1959.

Water is subject to certain standards, controls and issues of equitable distribution of dwindling water supplies are becoming more serious, where there is excess use of water at the beginnings of the canals or obvious lack of water supply at the ends, leading to decreased productivity for the main cultivated crops, and this led to damage productivity of cultivated lands .

\section{Mainobjectives:}

The study is concentrated on the creation of water users associations and its role to optimum use of water resources on irrigated and reclaimed lands as well as it is focused also on the impact of the site in distribution of water along the Masqa and reduce differences in water size distributed, so so the main objectives can be summarized as :

1. Measuring the impact of the farm site on masqa at the optimum productivity levels and maximizing profit of wheat producers . 
2. Estimate the farm income loss and net profit loss for wheat producers due to the lack of optimum use of resources and access to level of profit maximization of agricultural inputs.

3. Measuring the amount of improvement in the self-sufficiency ratios of wheat crop.

\section{Data Sources}

The study depends on two types of data firstly: Secondary data published and unpublished from the Ministry of Agriculture and the Department of Agriculture at Sharkia governorate, In addition to accomplish the previous objectives a questionnaire sheets has been designed to collect and conduct a suitable primary field data applied on a random intentional sample Sharkia governorate in Faqous and Abou-Hamad because the majority of water links exist in these two centers .It were selected three villages in Abou-Hmad (the Almazemih - Manshiet Saeed - Abu Hagar). It has been selected in Faqous (Alrawda - Ibn Amr) because they are the largest area wherehave been carried out irrigation project development . In addition wheat farmers has been selected randomly through a personal interview during the period from January to March in 2015.

\section{Methodology}

The study used both quantitative and descriptive analysis represented in using the total cost approach and the average cost approach to measure the impact of the farm location at the masqa on the levels of optimum and actual productivity and also on maximizing profit of wheat production. So total cost approach and the average cost approach can be illustrated as follows:

\subsection{The total cost approach}

All costs faced by companies can be broken into two main categories: fixed costs and variable costs. Fixed costs are costs that are independent of output. These remain constant throughout the relevant range and are usually considered sunk for the relevant range (not relevant to output decisions). Fixed costs often include rent, buildings, machinery, etc. Variable costs are costs that vary with output. Generally variable costs increase at a constant rate relative to labor and capital. Variable costs may include wages, utilities, materials used in production, etc. Total costs are the summation of both fixed costs and the variable costs.

\subsection{The average cost approach}

The average costs can be divided into four categories:

i. Average fixed cost ( AFC) is the fixed cost per unit of output and can be determined with the following equation:

Average Fixed Cost $=$ Total Fixed Cost $/$ Total Units of Output.

ii. Average variable cost (AVC) is the total variable cost per unit of output. This is found by dividing total variable cost (TVC) by total output (Q), It's a U-shaped curve. Initially, the variable cost per unit of output decreases as output increases. At one point, it reaches a low. After the low, the variable cost per unit of output starts to increase. The increase in AVC after a certain point is indirectly related to 
the law of diminishing marginal returns. The law states that at some point, the additional cost incurred to produce one more unit is greater than the additional revenue (or returns) received. At that point, the AVC starts to increase, and it can be determined with the following equation:

\section{$\mathrm{AVC}=$ Variable cost / Output}

Profit-maximizing firms will use the AVC to determine at what point they should shut down production in the short run. If the price they are receiving for the good is more than the AVC given the output they are producing, then they are at least covering all variable costs and some fixed costs.

iii. Average total cost is sometimes referred to as the per unit total cost since it is calculated by taking the total cost of production and dividing that by the number of units produced (quantity). In variable form, it looks like this:

\section{$\mathbf{A T C}=\mathbf{T C} / \mathrm{Q}$}

iv. Marginal Cost (MC) of an additional unit of output is the cost of the additional inputs needed to produce that output. More formally, the marginal cost is the derivative of total production costs with respect to the level of output.

\section{Results}

\subsection{Cultivated area}

Wheat crop production, productivity, cultivated area, total production value and net revenue in Egypt during 2000-2013 period are presented in Table (1). Data shown in the table have evident fluctuations between increases and decreases during the study period, reached to its minimum value 2,341,800 thousand Fadden in 2001 and a maximum value is estimated 3378 thousand Fadden in 2013 , as its total average is about 2,845,380 thousand Fadden and the total growth rate is increased by $2.5 \%$.during the studied period.

While wheat crop production, productivity, cultivated area, total production value and net revenue in Sharkia governorate during 2000-2013 period are presented in Table (2). Data shown in the table is moved to increase in general reached to its minimum value 271,100 thousand Fadden, while a maximum value is estimated 432,430 thousand Fadden in 2013, as its total average is about 356,440 thousand Fadden and the total growth rate is increased by $2.93 \%$ during the studied period.

\subsection{Productivity}

Data shown in table (1) are fluctuated during the study period ( 2000-2013) between a minimum value which is about 17.77 ardab/Fadden in 2000 and a maximum value is estimated at 18.67 ardab/Fadden in 2013 , also its total average is $18.18 \mathrm{ardab} /$ Fadden and the total growth rate is increased approximately $0.35 \%$.

In addition, Data shown in table (2) the is oscillated between increasing and decreasing, reached the minimum value 17 ardab/Fadden in 2001 and the maximum value $20.3 \mathrm{ardab} /$ Fadden in 2007, also data is illustrated that the average of productivity of wheat crop is amounted to $18.22 \mathrm{ardab} /$ Fadden, and during the same period the annual growth rate increased about $0.36 \%$.

\subsection{Total production}

Data shown in table (1) is oscillated between increase and decrease, reached the minimum value 41707.460 thousand ardabs in 2001 , and the maximum value is 
about 63,076 thousand ardabs in 2013 and the total average is estimated about 51772.920 thousand ardabs and the total growth rate is increased by $3 \%$ during the studied period.

While data shown in table (2) is oscillated between increase and decrease reached to its minimum value 184.280 thousand ardabs in 2009 , while a maximum value is estimated 7999.960 thousand ardabs in 2013, as its total average is about 5984.480 thousand ardabs and the total growth rate is increased by $3.29 \%$ during the studied period.

\subsection{Total production value}

Data shown in table (1) are fluctuated between a minimum value which is about $1851.6 \mathrm{~L} . \mathrm{E} /$ Fadden in 2000 and a maximum value is estimated at 9088 L.E/Fadden in 2012, also its total average is 4884.6 L.E/Fadden and the total growth rate is increased approximately $12.03 \%$.

Moreover data shown in table (2) is oscillated between increasing and decreasing, reached the minimum value 1797.25 L.E/Fadden in 2001 and the maximum value $9019.5 \mathrm{~L}$.E/Fadden in 2013, also data is illustrated that the average of total production value of wheat crop is amounted to $4747.21 \mathrm{~L} . \mathrm{E} / \mathrm{Fadden}$, and during the same period the annual growth rate increased about $11.74 \%$.

\subsection{Net revenue}

Data shown in table (1) have evident fluctuations between increases and decreases during the study period, reached to its minimum value $897 \mathrm{~L}$.E/Fadden in 2000 and a maximum value is estimated 5159 L.E/Fadden in 2007, as its total average is about 2639.2 L.E/Fadden and the total growth rate is increased by $11.8 \%$.during the studied period.

Table (1): Wheat crop production, productivity, cultivated area, total production value and net revenue in Egypt, 2000-2013.

\begin{tabular}{|c|c|c|c|c|c|}
\hline Year & $\begin{array}{c}\text { Cultivated } \\
\text { area } \\
\text { (thousand } \\
\text { Fadden) }\end{array}$ & $\begin{array}{c}\text { Productivity } \\
\text { (ardab / } \\
\text { Fadden) }\end{array}$ & $\begin{array}{c}\text { Total } \\
\text { production } \\
\text { (thousand } \\
\text { ardab) }\end{array}$ & $\begin{array}{c}\text { Total } \\
\text { production } \\
\text { value } \\
\text { (L.E / Fadden) }\end{array}$ & $\begin{array}{c}\text { Net } \\
\text { revenue } \\
\text { (L.E / } \\
\text { Fadden) }\end{array}$ \\
\hline $\mathbf{2 0 0 0}$ & 2463.3 & 17.77 & 43772.84 & 1851.6 & 897 \\
\hline $\mathbf{2 0 0 1}$ & 2341.8 & 17.81 & 41707.46 & 1871.8 & 972 \\
\hline $\mathbf{2 0 0 2}$ & 2450.4 & 18.02 & 44156.21 & 1940.8 & 1016 \\
\hline $\mathbf{2 0 0 3}$ & 2506.2 & 18.21 & 45637.91 & 2075.9 & 1666 \\
\hline $\mathbf{2 0 0 4}$ & 2605.5 & 18.37 & 47863.03 & 2755.5 & 1956 \\
\hline $\mathbf{2 0 0 5}$ & 2985.3 & 18.18 & 54272.75 & 3937 & 1863 \\
\hline $\mathbf{2 0 0 6}$ & 3063.7 & 18 & 55146.6 & 4006 & 1769 \\
\hline $\mathbf{2 0 0 7}$ & 2715.5 & 18.12 & 49204.86 & 4213 & 5159 \\
\hline $\mathbf{2 0 0 8}$ & 2920.4 & 18.21 & 53180.48 & 8304 & 2190 \\
\hline $\mathbf{2 0 0 9}$ & 3147 & 18.06 & 56834.82 & 5649 & 3448 \\
\hline $\mathbf{2 0 1 0}$ & 3048.6 & 18.22 & 55545.49 & 5657 & 3884 \\
\hline $\mathbf{2 0 1 1}$ & 3048.6 & 18.3 & 55789.38 & 7953 & 4274 \\
\hline $\mathbf{2 0 1 2}$ & 3161 & 18.55 & 58,633 & 9088 & 3581 \\
\hline $\mathbf{2 0 1 3}$ & 3378 & 18.67 & 63,076 & 9082 & 4274 \\
\hline Average & 2845.38 & 18.18 & 51772.92 & 4884.61 & 2639.21 \\
\hline Growth rate & $2.28 \%$ & $0.35 \%$ & $2.64 \%$ & $12.03 \%$ & $11.80 \%$ \\
\hline Source: Mis & & & & \\
\hline
\end{tabular}

Source: Ministry of Agriculture and Land Reclamation, Economic Affairs Sector, Central Administration of Agricultural Economics, Agricultural Economics Bulletin, various issues. 
Table 2: Wheat crop production, productivity, cultivated area and net revenue in Sharkia governorate , (2000-2013).

\begin{tabular}{|c|c|c|c|c|c|}
\hline Year & $\begin{array}{c}\text { Cultivated area } \\
\text { (thousand } \\
\text { Fadden) }\end{array}$ & $\begin{array}{c}\text { Productivity } \\
\text { (ardab/ } \\
\text { Fadden) }\end{array}$ & $\begin{array}{c}\text { Total } \\
\text { production } \\
\text { (thousand } \\
\text { ardab) }\end{array}$ & $\begin{array}{c}\text { Total } \\
\text { production } \\
\text { value } \\
\text { (L.E / Fadden) }\end{array}$ & $\begin{array}{c}\text { Net revenue } \\
\text { (L.E / } \\
\text { Fadden) }\end{array}$ \\
\hline $\mathbf{2 0 0 0}$ & 288.80 & 17.60 & 5082.88 & 1905.72 & 525.72 \\
\hline $\mathbf{2 0 0 1}$ & 271.10 & 17.00 & 4608.70 & 1797.25 & 401.25 \\
\hline $\mathbf{2 0 0 2}$ & 282.00 & 18.20 & 5132.40 & 3199.40 & 456.40 \\
\hline $\mathbf{2 0 0 3}$ & 308.50 & 19.20 & 5923.20 & 2804.30 & 110.30 \\
\hline $\mathbf{2 0 0 4}$ & 308.50 & 19.30 & 5954.05 & 3483.75 & 1279.25 \\
\hline $\mathbf{2 0 0 5}$ & 354.70 & 18.70 & 6632.89 & 3988.00 & 1585.00 \\
\hline $\mathbf{2 0 0 6}$ & 375.12 & 20.10 & 7539.91 & 3903.00 & 1650.00 \\
\hline $\mathbf{2 0 0 7}$ & 346.36 & 20.30 & 7031.11 & 4162.00 & 1782.00 \\
\hline $\mathbf{2 0 0 8}$ & 375.30 & 16.80 & 6305.04 & 7684.00 & 4213.00 \\
\hline $\mathbf{2 0 0 9}$ & 418.42 & 17.17 & 184.28 & 5247.00 & 1246.00 \\
\hline $\mathbf{2 0 1 0}$ & 399.92 & 16.70 & 6678.66 & 3976.00 & 1668.00 \\
\hline $\mathbf{2 0 1 1}$ & 403.98 & 17.20 & 6948.46 & 7220.00 & 2683.00 \\
\hline $\mathbf{2 0 1 2}$ & 425.04 & 18.26 & 7761.23 & 8071.00 & 3334.00 \\
\hline $\mathbf{2 0 1 3}$ & 432.43 & 18.50 & 7999.96 & 9019.50 & 3804.00 \\
\hline Average & 356.44 & $18: 22$ & 5984.48 & 4747.21 & 1766.99 \\
\hline Growth rate & $2.93 \%$ & $0.36 \%$ & $3.29 \%$ & $11.74 \%$ & $15.18 \%$ \\
\hline
\end{tabular}

Source: Agriculture directorate Sharkia governorate, management of the agricultural statistics department, unpublished data.

While data in table (2) is oscillated between increasing and decreasing reached to its minimum value $110.3 \mathrm{~L} . \mathrm{E} /$ Fadden in 2003, while a maximum value is estimated 4214 L.E/Fadden in 2008, as its total average is about 1766.99 L.E/Fadden and the total growth rate is increased by $15.18 \%$ during the studied period.

\subsection{The structure of total revenue, total costs and profit of sample according to location of cultivated lands on the Masqa.}

To find out the impact of the location in distribution of water along the Masqa and reduce differences and disparities in distributed water volume so 160 producers of wheat crop has been divided along Masqa the into three groups based on their site along Masqa as follow : (a)At the head ( 1st group). (b) At the middle ( 2nd group). (c) At the end (3rd group). Total revenues, total costs and profits of sample according to the farm location along Masqa (Head, middle, tail) in 2012 are presented in Table (3). Data shown in the table has revealed that farm gate price has reached 425 L.E / ardab.

- Average of quantity production of wheat crop along Masqa was about 18.191 ardab / Fadden, as the average of quantity production of wheat crop was estimated at 18.597, 19.19 and 16.73 ardabs / Fadden at head, middle, and tail of masqa respectively. So average of quantity production of wheat crop at middle of masqa is greater than the average of head and tail masqa. Total revenue of the wheat crop along Masqa as its average is estimated $7731.18 \mathrm{~L} . \mathrm{E} /$ Fadden, while average of total revenue at the head, middle and tail of Masqa is 7903.73 , 8153.63 , 7108.55 L.E / Fadden respectively, which refers to the superiority of the wheat crop total revenue of middle masqa.

- Total cost of wheat crop along Masqa, which is amounted to 6602.95 L.E / Fadden (fixed costs 2428.5 L.E/Fadden, variable costs 4174.45 L.E / Fadden), while total 
costs at the head of Masqa is amounted 6584.24 L.E / Fadden (divided into fixed costs 2420.31 L.E / Fadden and variable costs is 4163.94 L.E / Fadden), in addition total costs at the middle of Masqa is 6885.74 L.E/ Fadden (divided into fixedcosts 2605.09 L.E/ Faddenand the variable costs is 4280.65 L.E /Fadden), also total costs At the end of Masqa is $6322.91 \mathrm{~L}$.E / Fadden (divided into fixed costs 2250 L.E / Fadden and variable costs 4072.91 L.E / Fadden), which indicates the middle of masqa has the highest total costs of wheat crop. Average total cost of wheat along Masqa, which is amounted to 362.98L.E/Fadden (divided into average fixed costs 133.5 L.E / Fadden and average cost of a variable 229.48 L.E /Fadden), while the average total cost at the head of Masqa 354.05 L.E /Fadden (divided into average fixed costs 130.15 L.E/Fadden and average variable costs 223.9 L.E /Fadden), in addition average total costs at middle of masqa 358.91 L.E / Fadden (divided into average fixed costs 135.79 L.E/ Fadden and average variable costs 223.12 L.E / Fadden), also average total costs at the end of Masqa 378.03 L.E /ardabs (divided into average fixed costs 134.2 L.E / Fadden and average variable costs 243.51 L.E /Fadden), which is indicated that the average total cost of wheat crop at the end of Masqa is greater than head and middle of masqa.

Table (3): Total revenues, total costs and profits of sample according to the farm location along Masqa (Head, middle, tail), in 21015.

\begin{tabular}{|c|c|c|c|c|c|}
\hline Items & Unit & Head & Middle & Tail & Along Masqa \\
\hline Quantity of production & Ardabs/Fadden & 18.597 & 19.185 & 16.726 & 18.191 \\
\hline Price & L.E/ Ardabs & 425 & 425 & 425 & 425 \\
\hline Total revenue & L.E/Fadden & 7903.725 & 8153.625 & 7108.55 & 7731.175 \\
\hline Variable costs & L.E/Fadden & 4163.937 & 4280.648 & 4072.906 & 4174.446 \\
\hline Fixed costs & L.E/Fadden & 2420.306 & 2605.093 & 2250 & 2428.503 \\
\hline Total costs & L.E/Fadden & 6584.243 & 6885.741 & 6322.906 & 6602.949 \\
\hline Average variable costs & L.E/ Ardabs & 223.9037 & 223.1247 & 243.5075 & 229.4786 \\
\hline Average fixed costs & L.E/ Ardabs & 130.145 & 135.788 & 134.5211 & 133.5003 \\
\hline Average total costs & L.E/ Ardabs & 354.049 & 358.913 & 378.029 & 362.979 \\
\hline Profit & L.E/ Ardabs & 70.951 & 66.087 & 46.971 & 62.021 \\
\hline Profit & L.E/Fadden & 1319.482 & 1267.884 & 785.644 & 1128.226 \\
\hline
\end{tabular}

Source: collected and calculated from a sample survey data.

- Wheat crop profit along Masqa (average profit) 1128.23 L.E / Fadden (62.02 L.E / ardabs), as the profit has reached at the head of Masqa about 1319.48 L.E /Fadden (70.95 L.E / ardabs), while it reached at the middle of masqa about 1267.88 L.E/ Fadden (66.09 L.E / ardabs), but it is estimated about 785.64 L.E / Fadden (49.67 L.E / ardabs) at the end of Masqa , so its indicated that profit of wheat crop at the head of Masqa is greater than the middle and Masqa.

\subsection{Maximization of wheat farmers income using averages total costs approach.}

\subsubsection{Along the Masqa}

By using average costs data of wheat crop production per ardab as a dependent variable and average productivity data of wheat crop per fadden as an independent variable, for estimating of average variable costs function (equation 1), average total costs function (equation 2) and marginal cost function ( equation 3) can be calculated as follows: 


$$
\begin{aligned}
& \mathrm{AVC}=771.76-53.32 \mathrm{x}+1.28 \mathrm{x}^{2} \\
& \overline{\mathbf{R}}^{2}=\mathbf{0 . 5 4 5} \\
& \text { (10.05) (-6.14) (5.25) }
\end{aligned}
$$$$
\mathrm{ATC}=1077.91-70.04 \mathrm{x}+1.68 \mathrm{x}^{2}
$$$$
\text { - (13.14) (-7.55) (6.44) }
$$$$
\hat{\mathbf{R}}^{2}=\mathbf{0 . 6 5 6} \quad \mathrm{F}=\mathbf{1 4 9 . 7 6}
$$

$M C=1077.91-140.08 x+5.03 x^{2}$

Where:

ATC $=$ Average total cost along the masqa by L.E per ardab.

$\mathrm{AVC}=$ Average variable cost along the masqa by L.E per ardab.

$\mathrm{Mc}=$ Marginal costs along the masqa by L.E per ardab.

$\mathrm{X}=$ Quantity of production along the masqa by ardab.

The estimated average total variable function is being Statistically significant as $\mathrm{f}$ - calculated value is 94.5 , also the value of adjusted determination coefficient was estimated at 0.545 , which indicated that $54.5 \%$ of the variations in average variable cost of wheat crop production due to the change in wheat productivity along masqa, in addition the estimated parameters of average variable costs function (equation 1) is being Statistically significant at the significant level 0.05 as it is estimated about 6.14 and 5.25, respectively.

The estimated average total cost function is being Statistically significant as fcalculated value is 149.76 , also the value of adjusted determination coefficient was estimated at 0.656 , which indicated that $65.6 \%$ of the variations in average total cost of wheat crop production due to the change in wheat productivity along masqa, in addition the estimated parameters of average total costs function (equation 2) is being Statistically significant at the significant level 0.05 as it is estimated about -7.55 and 6.44, respectively, so the following results can be concluded through figure (1).

Figure 1 : Average of total cost, variable and fixed costs curves, marginal cost curve, and farmgate price curve of wheat producers along Masqa in a sample study .

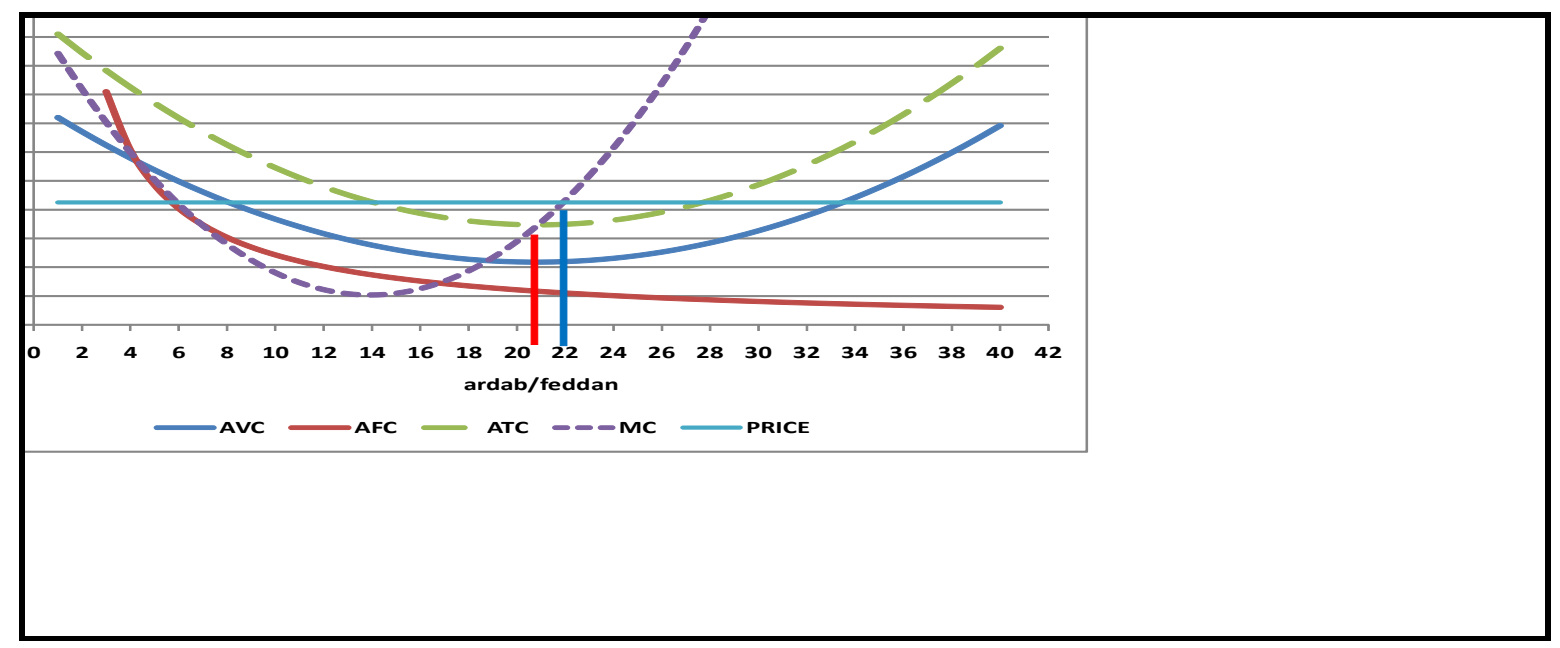

Source: collected and calculated from a sample survey data in 2015. 
- Average total cost curve of wheat crop along Masqa take U shape. This means that the average total cost decreased by the increasing of wheat productivity until a certain level is 20.87 ardabs ( as the production of other extra ardabs after the level of production 20.87 ardabs added lower quantity than the previous ardabs to the average total cost due to the efficiency of some or all of the production factors). The average total cost start after the previous production level increase (as the production of other extra ardabs after the level of production 20.87 ardabs added greater quantity than the previous ardabs to the average total cost due to the inefficiency of some or all of the production inputs). So that it can be concluded that the production level that minimize the average total cost to produce ardab of wheat crop along Masqa is estimated about 20.87 ardabs by average total costs were estimated at 346.86 L.E per ardab.

- Marginal cost curve of wheat crop along Masqa take U shape because it has been derived from the average total cost function. The marginal costs curve intersects average total cost curve of wheat crop at the lowest value of the last one (346.86 LE/ardabs) when its reached to production level 20.87 ardabs.

- The volume of production that maximized wheat crop revenue along Masqa can be derived when marginal costs curve is equal to farm gate price for ardab (i.e., marginal revenue ). Therefore the maximizes profit is estimated at 21.91 ardabs and the average costs of production at that production level is estimated at 348.67 LE/ardabs.

\subsection{2.. Head of Masqa}

By using average costs data of wheat crop production per ardab at the head of masqa as a dependent variable and average productivity data of wheat crop per fadden of wheat crop at the head of masqa as an independent variable, for estimating of average variable costs function (equation 4) average total costs function (equation 5 ) and marginal cost function ( equation 6) at head of masqa , can be calculated as follows:

$$
\begin{aligned}
& A V C=893.51-68.39 x+1.71 x^{2} \\
& \text { (4.23) (-2.98) (2.79) } \\
& \dot{R}^{2}=\mathbf{0 . 2 5 7} \quad \mathbf{F}=\mathbf{1 0 . 1 8} \\
& \text { (4.93) (-2.82) (2.45) } \\
& \mathbf{R}^{2}=\mathbf{0 . 4 7} \quad \mathbf{F}=\mathbf{2 4 . 5 1} \\
& M C=997.9-123.82 X+4.38 X^{2}
\end{aligned}
$$

Where:

ATC $=$ Average total cost at head of masqa by L.E per ardab.

$\mathrm{AVC}=$ Average variable cost at head of masqa by L.E per ardab.

$\mathrm{Mc}=$ Marginal cost at head of the masqa by L.E per ardab.

$\mathrm{X}=$ Quantity of production at head of masqa by ardab.

It is shown that the estimated average variable cost function is being Statistically significant as $\mathrm{f}$ - calculated value is 10.18 , also the value of adjusted 
determination coefficient was estimated at 0.257 , which indicated that $25.7 \%$ of the change in average variable cost of wheat crop production due to the change in wheat productivity at the head of masqa, in addition the estimated parameters of average variable costs function (equation 4) is being Statistically significant at the significant level 0.05 as it is estimated about -2.98 and 2.79 , respectively.

It is also shown that the estimated average total cost function is being Statistically significant as $\mathrm{f}$ - calculated value is 24.51 , also the value of adjusted determination coefficient was estimated at 0.47 , which indicated that $47 \%$ of the change in average total cost of wheat crop production due to the change in wheat productivity at the head of masqa, in addition the estimated parameters of average total costs function (equation 5) is being Statistically significant at the significant level 0.05 as it is estimated about -2.82 and 2.45 , respectively. So the following results can be concluded through figure (2):

Figure 2 : Average of total cost, variable and fixed costs curves, marginal cost curve, and farm gate price curve of wheat producers at the head of Masqa in a sample study

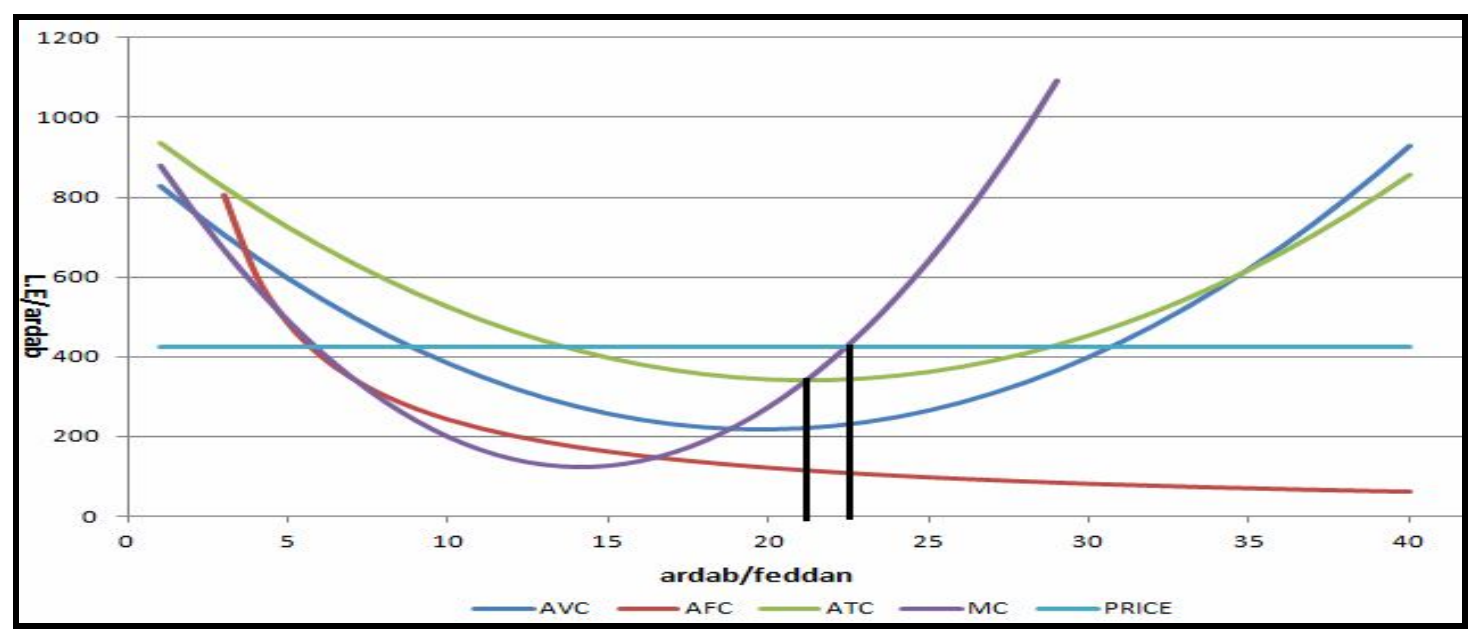

Source: collected and calculated from a sample survey data, in 2015.

- Average total cost curve of wheat crop at the head of Masqa take U shape. This means that the average total cost decreased by the increasing of wheat productivity until a certain level is 21.19 ardabs ( as the production of other extra ardabs after the level of production 21.19 ardabs added lower quantity than the previous ardabs to the average total cost due to the efficiency of some or all of the production factors). The average total cost start after that production level increase (as the production of other extra ardabs after the level of production 21.19 ardabs added greater quantity than the previous ardabs to the average total cost due to the inefficiency of some or all of the production inputs). So that it can be concluded that the production level that minimize the average total cost to produce ardab of wheat crop at the head of Masqa is estimated about 21.19 ardabs by average total costs were estimated at 341.76 L.E per ardab.

- Marginal cost curve of wheat crop at the head of Masqa take U shape because has been derived from the average total cost function. The marginal cost curve intersects with average total cost curve of wheat crop at the lowest value of the last one (341.76 L.E/ardabs) when its reached to production level 21.19 ardabs. 
- The volume of production that maximized wheat crop revenue at the head of Masqa can be derived when marginal costs function is equal to farm gate price for ardab of wheat crop at head of Masqa (i.e., marginal revenue ). Therefore the maximizes profit is estimated about 22.43 ardabs and the average costs of production at that production level is estimated at 343.91 L.E/ardabs.

\subsubsection{Middle of Masqa}

By using average cost data of wheat crop production per ardab at the middle of masqa as a dependent variable and average productivity data of wheat crop per fadden of wheat crop at the middle of masqa as an independent variable, for estimating of average variable cost function (equation 7) average total costs function (equation 8) and marginal cost function ( equation 9) at middle of masqa , can be calculated as follows:

$$
\begin{aligned}
& A V C=969.45-73.37 x+1.79 x^{2} \\
& \text { (5.11) (-3.57) (3.23) } \\
& \mathbf{R}^{2}=\mathbf{0 . 4 5 2} \quad \mathbf{F}=\mathbf{2 2 . 8 5} \\
& \mathrm{ATC}=1568.13-121.02 \mathrm{x}+3.01 \mathrm{x}^{2} \\
& \text { (6.99) (-4.98) (4.59) } \\
& \mathbf{R}^{2}=\mathbf{0 . 5 5 1 3} \quad \mathrm{F}=\mathbf{3 3 . 5 6} \\
& M C=1568.13-242.04 X+9.02 X^{2}
\end{aligned}
$$

ATC $=$ Average total cost at middle of masqa by L.E per ardab.

$\mathrm{AVC}=$ Average variable cost at middle of masqa by L.E per ardab.

$\mathrm{Mc}=$ Marginal cost at middle of the masqa by L.E per ardab.

$\mathrm{X}=$ Quantity of production at middle of masqa by ardab.

It is shown that the estimated average variable cost function is being Statistically significant as $\mathrm{f}$ - calculated value is 22.85 , also the value of adjusted determination coefficient was estimated at 0.452 , which indicated that $45.2 \%$ of the change in average variable cost of wheat crop production due to the change in wheat productivity at the middle of masqa, in addition the estimated parameters of average variable costs function (equation 7) is being Statistically significant at the significant level 0.05 as it is estimated about -3.57 and 3.23 , respectively

Moreover, It is shown that the estimated average total cost function is being Statistically significant as f- calculated value is 33.56 , also the value of adjusted determination coefficient was estimated at 0.5513 , which indicated that $55.13 \%$ of the change in average total cost of wheat crop production due to the change in wheat productivity at the middle of masqa, in addition the estimated parameters of average total costs function (equation 8) is being Statistically significant at the significant level 0.05 as it is estimated about -4.98 and 4.59 , respectively. So the following results can be concluded through figure 3 : 
Figure 3 : Average total cost, variable and fixed costs curves, marginal cost curve, and farm gate price curve of wheat producers at the middle of Masqa in a sample study

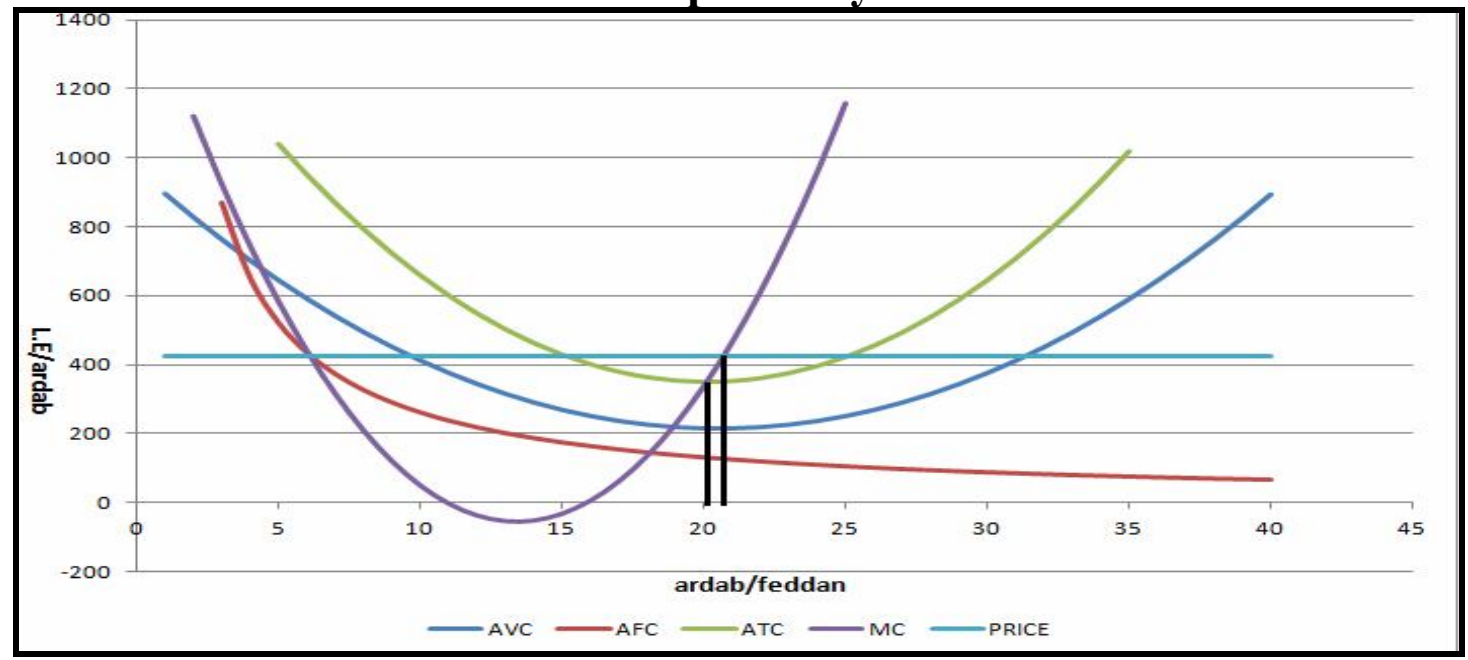

Source: collected and calculated from a sample survey data in 2015.

- Average total cost curve of wheat crop at the middle of Masqa take U shape. This means that the average total cost decreased by the increasing of wheat productivity until a certain level is 20.12 ardabs ( as the production of other extra ardabs after the level of production 20.12 ardabs added lower quantity than the previous ardabs to the average total cost due to the efficiency of some or all of the production factors). The average total cost start after that production level increase ( as the production of other extra ardabs after the level of production 20.12 ardabs added greater quantity than the previous ardabs to the average total cost due to the inefficiency of some or all of the production factors). So that it can be concluded that the production level that minimize the average total cost to produce ardab of wheat crop at the middle of Masqa is estimated about 20.12 ardabs by average total costs were estimated at 350.83 L.E per ardab.

- Marginal cost curve of wheat crop at the middle of Masqa take U shape because it can be derived from the average total cost function. The marginal costs curve intersects with average total cost curve of wheat crop at the lowest value of the last one ( 350.83 L.E/ardabs) when its reached to production level 20.12 ardabs.

- The volume of production that maximized wheat crop revenue at the middle of Masqa can be derived when marginal costs function is equal to farm gate price for ardab of wheat crop at head of Masqa (marginal revenue). Therefore the maximizes profit is estimated about 20.71 ardabs and the average costs of production at that production level is estimated at 351.9 L.E/ardabs

\subsubsection{End of Masqa}

By using average costs data of wheat crop production per ardab at the end of masqa as a dependent variable and average productivity data of wheat crop per fadden of wheat crop at the end of masqa as an independent variable, for estimating of average variable costs function (equation 10) average total costs function (equation 11) and marginal cost function ( equation 12) at end of masqa, can be calculated as follows: 


$$
\begin{aligned}
& \mathrm{AVC}=695.53-45.11 \mathrm{x}+1.076 \mathrm{x}^{2} \\
& \text { (5.76) (-3.11) (2.48) } \\
& \mathbf{R}^{2}=\mathbf{0 . 5 4 5 4} \quad \mathbf{F}=\mathbf{3 2 . 8} \\
& \mathrm{ATC}=942.59-53.77 \mathrm{X}+1.19 \mathrm{x}^{2} \\
& \text { (7.94) (-3.77) (2.79) } \\
& \mathbf{R}^{2}=\mathbf{0 . 7 4 4 1} \quad \mathbf{F}=\mathbf{7 4 . 1 3} \\
& M C=942.59-107.53 X+3.58 X^{2}
\end{aligned}
$$

ATC $=$ Average total cost at end of masqa by L.E per ardab.

$\mathrm{AVC}=$ Average variable cost at end of masqa by L.E per ardab.

$\mathrm{Mc}=$ Marginal cost at end of the masqa by L.E per ardab.

$\mathrm{X}=$ Quantity of production at end of masqa by ardab.

It is shown that the estimated average variable costs function is being Statistically significant as $\mathrm{f}$ - calculated value is 32.8 , also the value of adjusted determination coefficient was estimated at 0.5454 , which indicated that $54.54 \%$ of the change in average variable cost of wheat crop production due to the change in wheat productivity at the end of masqa, in addition the estimated parameters of average total costs function (equation 10) is being Statistically significant at the significant level 0.05 as it is estimated about -3.11 and 2.48 , respectively.

In addition, It is shown that the estimated average total costs function is being Statistically significant as $\mathrm{f}$ - calculated value is 74.13 , also the value of adjusted determination coefficient was estimated at 0.7441 , which indicated that $74.41 \%$ of the change in average total cost of wheat crop production due to the change in wheat productivity at the end of masqa, in addition the estimated parameters of average total costs function (equation 11) is being Statistically significant at the significant level 0.05 as it is estimated about -3.77 and 2.79 , respectively. So the following results can be concluded through figure (4):

Figure 4 : Average of total cost, variable and fixed costs curves, marginal cost curve, and farmgate price curve of wheat producers at the end of Masqa in a sample study

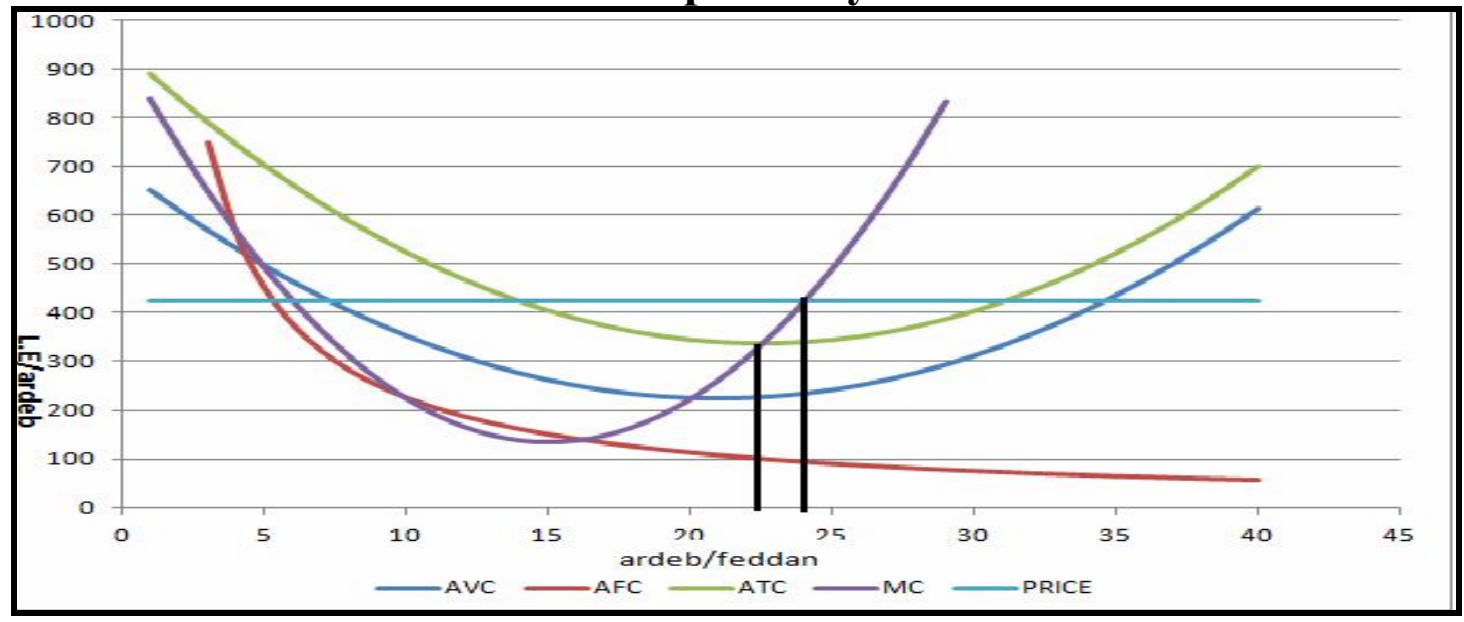

Source: collected and calculated from a sample survey data in 2015 . 
- Average total cost curve of wheat crop at the end of Masqa take U shape. This means that the average total cost decreased by the increasing of wheat productivity until a certain level is 22.54 ardabs ( as the production of other extra ardabs after the level of production 22.54 ardabs added lower quantity than the previous ardabs to the average total cost due to the efficiency of some or all of the production factors). The average total cost start after that production level increase (as the production of other extra ardabs after the level of production 22.54 ardabs added greater quantity than the previous ardabs to the average total cost due to the inefficiency of some or all of the production factors). So that it can be concluded that the production level that minimize the average total cost to produce ardab of wheat crop at the middle of Masqa is estimated about 22.54 ardabs by average total costs were estimated at 336.78 L.E per ardab.

- Marginal cost curve of wheat crop at the end of Masqa take U shape because it has be derived from the average total cost function. The marginal costs curve intersects with average total cost curve of wheat crop at the lowest value of the last one (336.78 L.E/ardabs) when its reached to production level 22.54 ardabs.

- The volume of production that maximized wheat crop revenue at the end of Masqa can be derived when marginal costs function is equal to farm gate price for ardab of wheat crop at end of Masqa ( marginal revenue ). Therefore, the maximizes profit is estimated about 24.03 ardabs and the average costs of production at that production level is estimated at $339.44 \mathrm{~L}$.E/ardabs.

\subsection{Maximizing wheat producers income by using the total cost approach.}

\subsubsection{Along masqa}

Although the total cost function of wheat crop along Masqa can be derived from the equation 2 ( average total cost) and can be calculated as follows :

$\mathrm{Tc}=1077.91 \mathrm{x}-70.04 \mathrm{x}^{2}+1.68 \mathrm{x}^{3}$

Where,

$\mathrm{TC}=$ Total cost along masqa by L.E per Fadden.

Figure 5 is indicated that the total cost approach to produce wheat crop along Masqa which is represented both of total cost curve and total revenue curve. Total revenue is a straight line started from the origin point, meaning that the total revenue is equal to zero at the beginning of production At any production levels is less than 13.34 ardabs or greater than 29.12 ardabs, the total costs are greater than the total revenue (causing loss). When the production level is reached to 13.34 ardabs or 29.12 ardabs so that the total revenue is equal to total costs (equivalent points or break even points). Production level that maximized profit is determined between these two production levels ( at 21.91 ardabs) when the slope of total revenue is equal to the slope of total cost.

\subsubsection{Head of masqa.}

Although the total cost function of wheat crop at the head of Masqa can be derived from the equation 5 ( average total cost) and can be calculated as follows :

$\mathrm{TC}=997.9 \mathrm{X}-61.91 \mathrm{X}^{2}+1.46 \mathrm{X}^{3}$

Where, 
$\mathrm{TC}=$ Total cost at the head of masqa by L.E per Fadden.

Figure ( 5 ) : Total, fixed and variable curves, total revenue curve, of wheat producers along Masqa in a sample study.

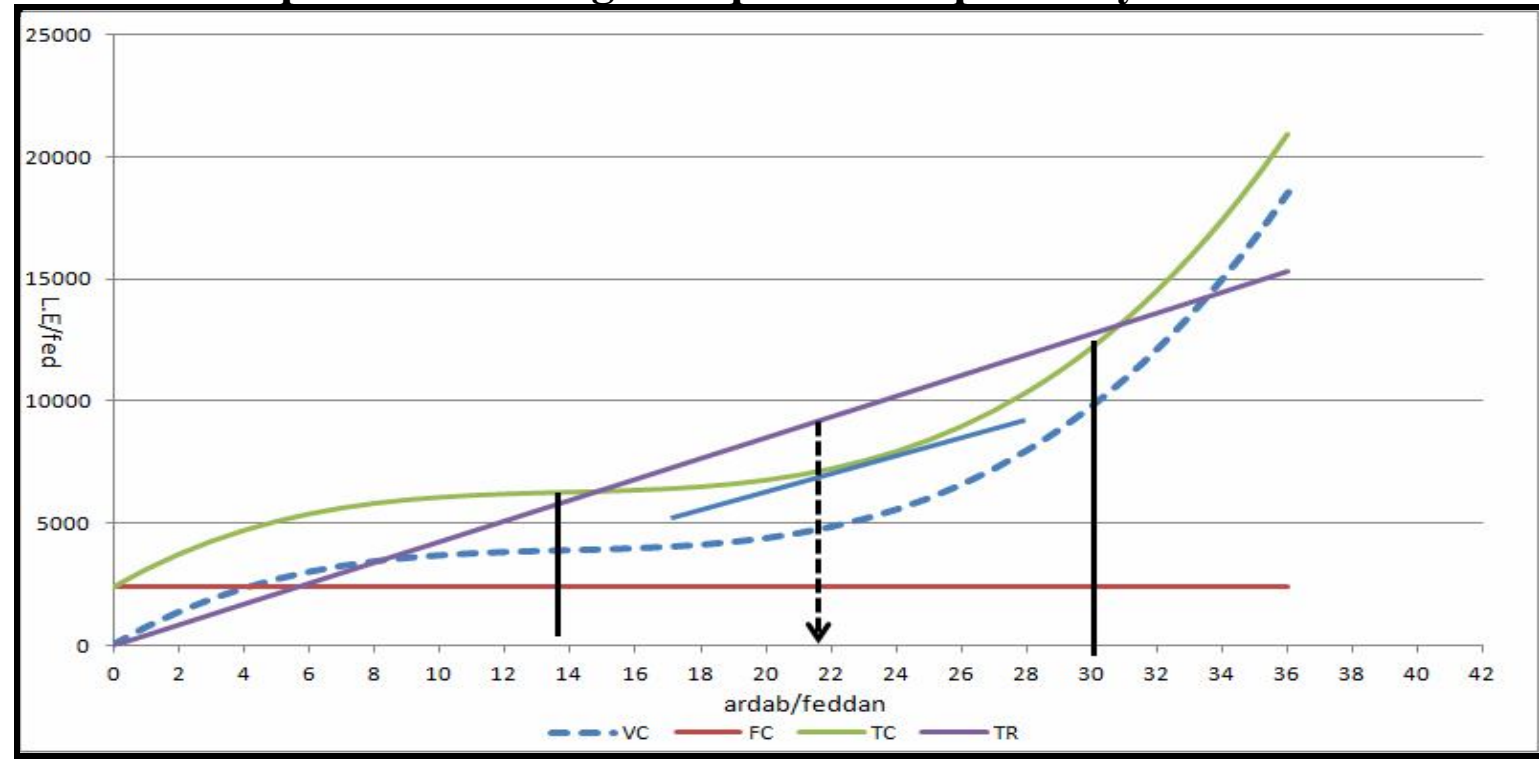

Source : collected and calculated from a sample survey data in 2015.

Figure (6) is indicated that the total cost approach to produce wheat crop at head of Masqa which is represented both of total cost curve and total revenue curve. Total revenue is a straight line started from the origin point, meaning that the total revenue is equal to zero at the beginning of production. At any production levels is less than 14.45 ardabs or greater than 27.18 ardabs, the total costs are greater than the total revenue (causing loss). When the production level is reached to 14.45 ardabs or 27.18 ardabs so that the total revenue is equal to total costs (equivalent points or break even points), Production level that maximized profit is determined between these two production levels ( at 22.44 ardabs) when the slope of total revenue is equal to the slope of total cost.

Figure ( 6 ) : Total cost, fixed and variable cost curves, total revenue curve, of wheat producers at head of Masqa in a sample study.

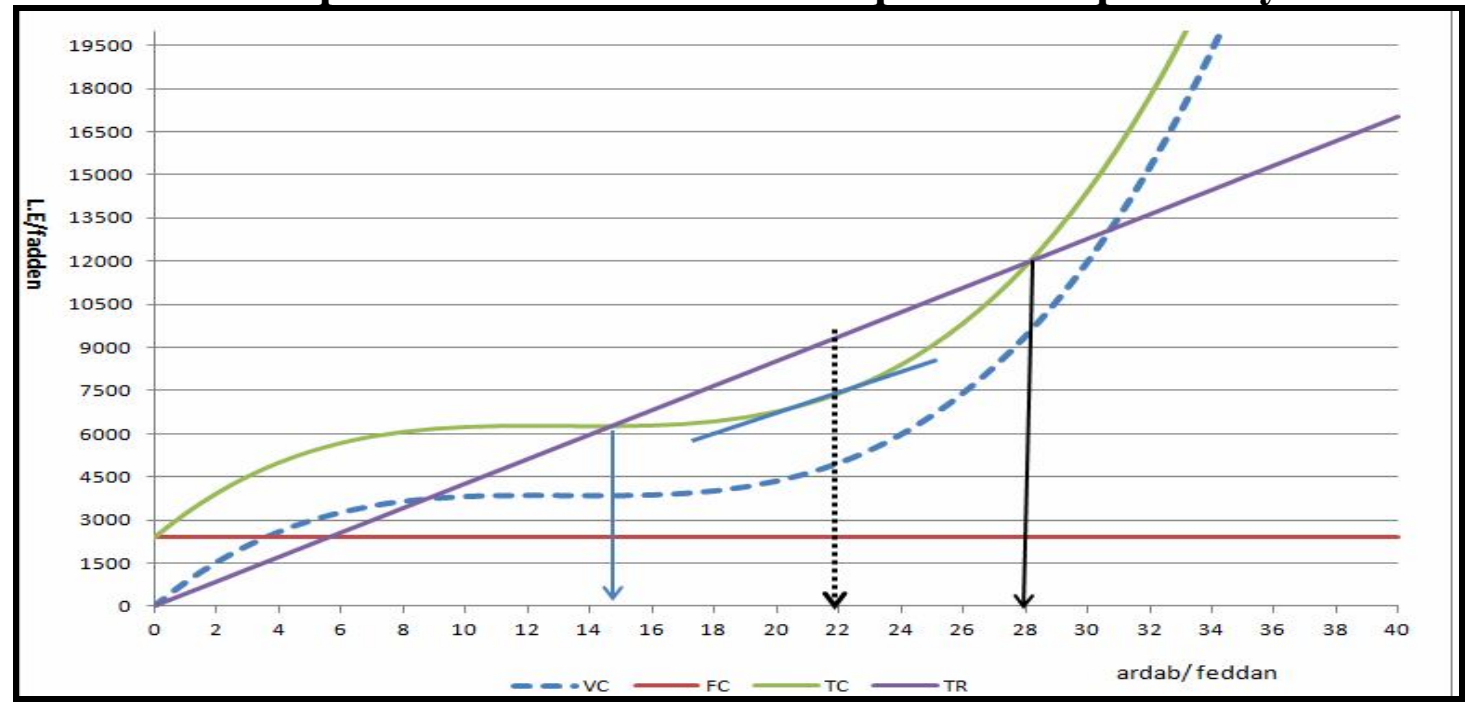

Source : Collected and calculated from a sample survey data in 2015 . 


\subsubsection{Middle of masqa.}

Although the total cost function of wheat crop at the middle of Masqa can be derived from the equation 8 ( average total cost) and can be calculated as follows :

$\mathrm{TC}=1568.13 \mathrm{X}-121.02 \mathrm{X}^{2}+3.01 \mathrm{X}^{3}$

Where,

$\mathrm{TC}=$ Total cost at the middle of masqa by L.E per Fadden.

Figure (7) is indicated that the total cost approach to produce wheat crop at middle of Masqa which is represented both of total cost curve and total revenue curve. Total revenue is a straight line started from the origin point, meaning that the total revenue is equal to zero at the beginning of production.

Figure ( 7 ) : Total, fixed and variable curves, total revenue curve, of wheat producers at middle of Masqa in a sample study.

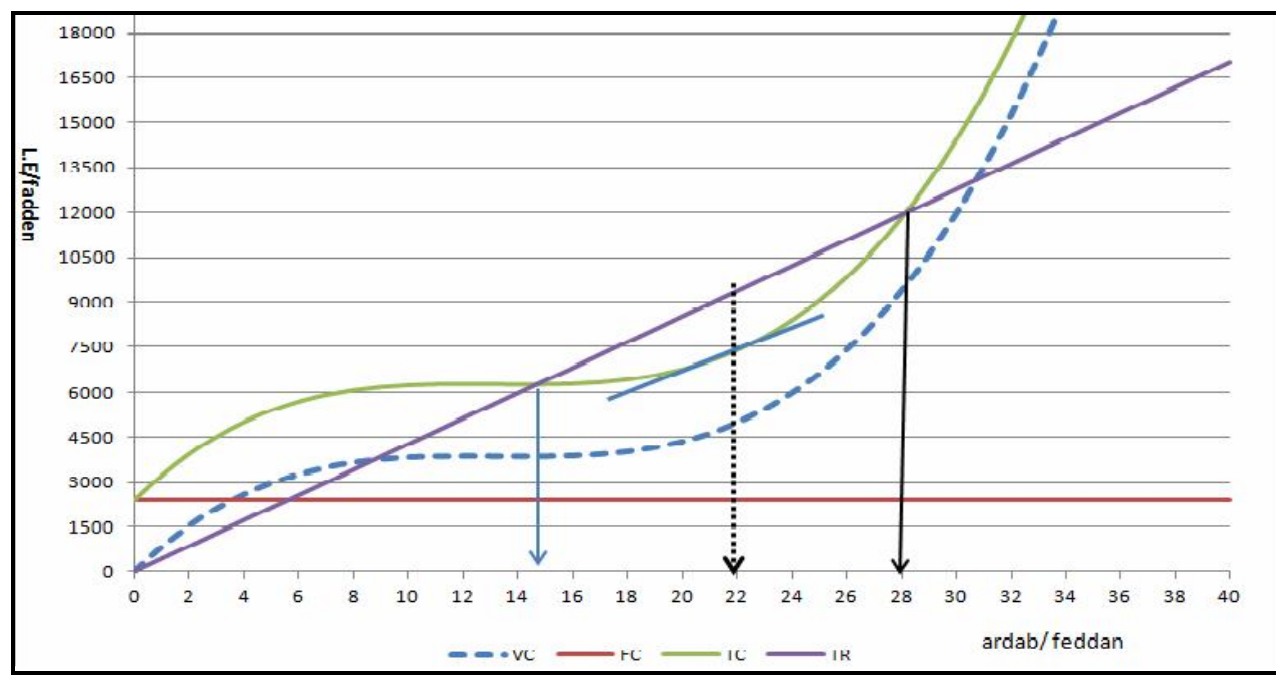

Source : collected and calculated from a sample survey data in 2015.

At any production level is less than 14.05 ardabs or greater than 27.15 ardabs, the total costs are greater than the total revenue (causing loss). When the production level is reached to 14.05 ardabs or 27.15 ardabs so that the total revenue is equal to total costs (equivalent points or break even points). Production level that maximized profit is determined between these two production levels ( at 20.71 ardabs) when the slope of total revenue is equal to the slope of total cost.

\subsubsection{End of masqa.}

Although the total cost function of wheat crop at the end of Masqa can be derived from the equation 11 ( average total cost) and can be calculated as follows : $\mathrm{TC}=942.59 \mathrm{X}-53.77 \mathrm{X}^{2}+1.19 \mathrm{X}^{3}$

Where, $\mathrm{TC}=$ Total cost at the end masqa by L.E per Fadden.

Figure (8) is indicated that the total cost approach to produce wheat crop at end of Masqa which is represented both of total cost curve and total revenue curve. Total revenue is a straight line started from the origin point, meaning that the total revenue is equal to zero at the beginning of production. At any production levels is less than 14.04 ardabs or greater than 31.24 ardabs, the total costs are greater than 
the total revenue (causing loss). When the production level is reached to 14.04 ardabs or 31.24 ardabs so that the total revenue is equal to total costs (equivalent points or break even points). Production level that maximized profit is determined between these two production levels ( at 24.03 ardabs) when the slope of total revenue is equal to the slope of total cost.

Figure ( 8 ) : Total, fixed and variable curves, total revenue curve, of wheat producers at end of Masqa in a sample study.

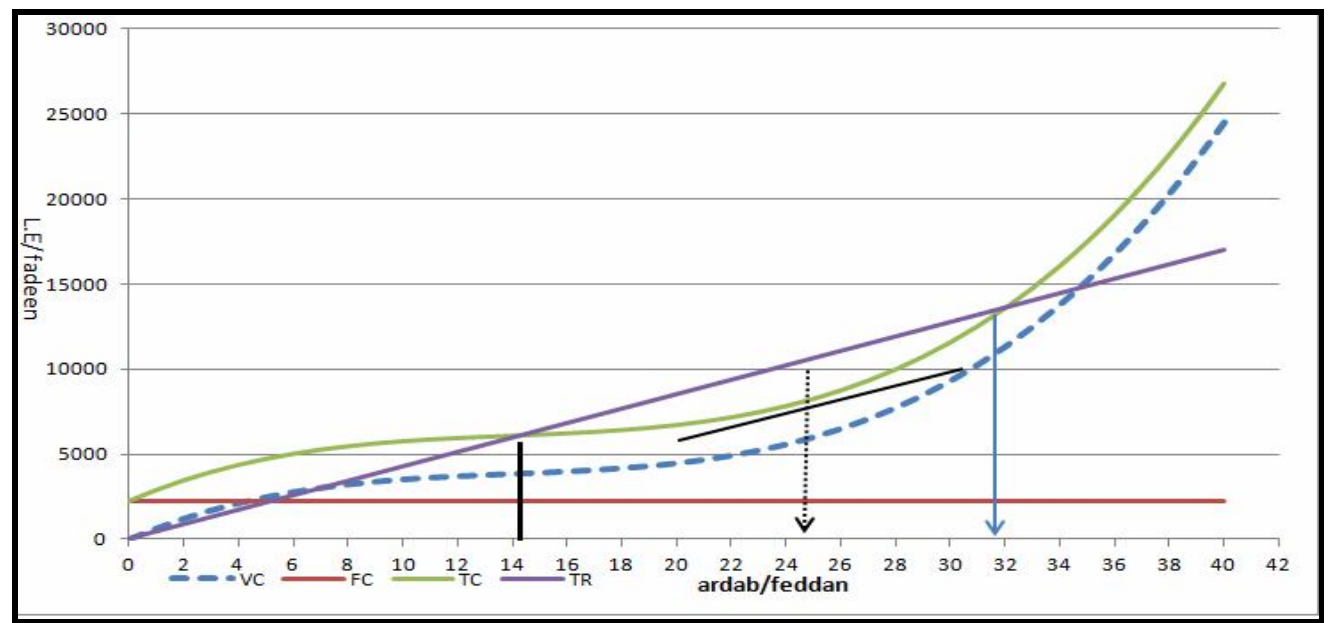

Source : collected and calculated from a sample survey data in 2015 .

\subsection{The income loss of wheat producer}

\subsubsection{Along masqa}

By applied the probabilistic model on data of sample under study to measure the average of actual wheat production and the cost of its unit, so that quantity of wheat production, profit loss of optimum production ( Net profit of optimum production - Net profit of actual production) and Profit loss of economic production ( Net profit of economic production - Net profit of actual production) of wheat producers along Masqa of sample study are presented in table (4), showed the following results:

- The average of farm price per ardab of wheat production along masqa was estimated about $425 \mathrm{~L} . \mathrm{E} / \mathrm{ardab}$. Also the average of the actual wheat production per fadden of wheat production was about 18.19 ardab/fadden. In addition average total cost of wheat production along masqa was estimated to be 362.98 L.E/ardab (6602.95 L.E/fadden), so that total revenue of actual wheat production was 7731.18 L.E/fadden, and net profit of actual wheat production along masqa was about 1128.23 L.E/fadden.

- Optimum wheat production along masqa was amounted about $20.87 \mathrm{ardab} /$ fadden and its average total cost was estimated at 346.95 L.E/ardab (7240.9 L.E/fadden). According the previous, total revenue of optimum wheat production was 8869.75 L.E/fadden, and net profit loss of actual wheat production along masqa was about 500.62 L.E/fadden.

- Quantity of wheat production maximizing profit (economic production) along masqa was about 21.91 ardab/fadden. Average total cost of economic production level along masqa was estimated at 348.73 L.E/ardab (7640.7 L.E/fadden), 
therefore total revenue was amounted to be 9311.75 L.E/fadden. Net profit loss is estimated to be $542.83 \mathrm{~L}$.E/fadden because the actual production level cannot be reached to economic production level that maximized profit along masqa, and that means the inefficient use of productive resources by wheat producers in the sample.

- Total costs of wheat production, average total cost, total revenue and net profit were differentiated from production level to another, so that net profit per ardab of wheat at level of optimum production was achieved to the most value that estimated about 78.05 L.E/ardab. Next production level that maximized profit was amounted to be 76.27 L.E/ardab then level of actual production was reached to the least value that estimated about 62.02 L.E/ardab. Net profit per ardab of wheat at actual production level was represented about $97.97 \%$ and $98.02 \%$ to both optimum and economic production, respectively.

- Because of not produced the level of optimum wheat production so that net profit loss was amounted to be 216.48 million L.E of area over Sharkia governorate, and about 1691.11 million L.E of area over Egypt. Also, because of not produced the level of wheat economic production ( maximizing profit) so that net profit loss was amounted to be estimated at 234.73 million L.E of area over Sharkia governorate, and about 1833.67 million L.E of area over Egypt.

Table ( 4 ) : Quantity of wheat production and profit loss of wheat producers along Masqa of sample study.

\begin{tabular}{|c|c|c|c|c|}
\hline Item & Unit & $\begin{array}{c}\text { Actual } \\
\text { production }\end{array}$ & $\begin{array}{c}\text { Optimum } \\
\text { production }\end{array}$ & $\begin{array}{c}\text { Economic } \\
\text { Production }\end{array}$ \\
\hline Quantity of production & Ardabs/Fadden & $18: 19$ & 20.87 & 21.91 \\
\hline Farm price & L.E/Ardabs & 425.00 & 425.00 & 425.00 \\
\hline Total revenue & L.E/Fadden & 7731.18 & 8869.75 & 9311.75 \\
\hline Total costs & L.E/Fadden & 6602.95 & 7240.90 & 7640.70 \\
\hline Average total costs & L.E/Ardabs & 362.98 & 346.95 & 348.73 \\
\hline Net Profit & L.E/Fadden & 1128.23 & 1628.85 & 1671.05 \\
\hline Net Profit & L.E/ Ardabs & 62.02 & 78.05 & 76.27 \\
\hline Revenue loss & L.E/Fadden & 0.00 & 1138.58 & 1580.58 \\
\hline Profit loss & L.E/Fadden & 0.00 & 500.62 & 542.83 \\
\hline $\begin{array}{c}\text { Profit loss in Sharkia } \\
\text { governorate }\end{array}$ & Million L.E & 0.00 & 216.48 & 234.73 \\
\hline Profit loss in Egypt & Million L.E & 0.00 & 1691.11 & 1833.67 \\
\hline
\end{tabular}

Source : collected and calculated from a sample survey data in 2015.

\subsubsection{At the head of masqa}

By applied the probabilistic model on data of sample under study to measure the average of actual wheat production and the cost of its unit, so that quantity of wheat production and profit loss of wheat producers at head of masqa of sample study are presented in table (5), showed the following results:

- The average of farm price per ardab of wheat production at head of masqa was estimated about $425 \mathrm{~L}$.E/ardab Also the average of the actual wheat production per fadden of wheat production was about 18.6 ardab/fadden. In addition average total cost of wheat production at head of masqa was estimated to be 354.05 L.E/ardab (6580.24 L.E/fadden). So that total revenue of actual wheat production was $7903.73 \mathrm{~L} . \mathrm{E} /$ fadden, and net profit of actual wheat production at head of masqa was about 1319.48 L.E/fadden. 
- Optimum wheat production at head of masqa was amounted about 21.19 ardab/fadden and its average total cost was estimated at 341.82 L.E/ardab (7243.2 L.E/fadden). So according the previous, total revenue of optimum wheat production was $9005.75 \mathrm{~L}$.E/fadden. Net profit loss of actual wheat production at head of masqa was about 443.07 L.E/fadden.

- Quantity of wheat production maximizing profit (economic production) at head of masqa was about $22.43 \mathrm{ardab} /$ fadden. Average total cost of economic production level at head of masqa was estimated at 344.02 L.E/ardab (7716.62 L.E/fadden). Total revenue was amounted to be $9532.75 \mathrm{~L}$.E/fadden. Net profit loss estimated to be $497 \mathrm{~L}$.E/fadden because the actual production level cannot be reached to economic production level that maximized profit at head of masqa, and that means the inefficient use of productive resources by wheat producers in the sample.

- Total costs of wheat production, average total cost and total revenue and net profit were differentiated from production level to another, so that net profit per ardab of wheat at level of optimum production was achieved to the most value that estimated about 83.18 L.E/ardab. Next production level that maximized profit was amounted to be $80.98 \mathrm{~L}$.E/ardab. Level of actual production was reached to the least value that estimated about $70.95 \mathrm{~L}$.E/ardab. Net profit per ardab of wheat at actual production level was represented about $82.77 \%$ and $85.86 \%$ to both optimum and economic production, respectively.

- Because of not produced the level of optimum wheat production so that net profit loss was amounted to be 191.6 million L.E of area over Sharkia governorate, and about 1496.68 million L.E of area over Egypt. Also, because of not produced the level of wheat economic production ( maximizing profit) so that net profit loss was amounted to be estimated at 214.92 million L.E of area over Sharkia governorate, and about 1678.88 million L.E of area over Egypt.

Table ( 5 ) : Quantity of wheat production and profit loss of wheat producers at head of Masqa of sample study.

\begin{tabular}{|c|c|c|c|c|}
\hline Item & Unit & $\begin{array}{c}\text { Actual } \\
\text { production }\end{array}$ & $\begin{array}{c}\text { Optimum } \\
\text { production }\end{array}$ & $\begin{array}{c}\text { Economic } \\
\text { Production }\end{array}$ \\
\hline Quantity of production & Ardabs/Fadden & 18.60 & 21.19 & 22.43 \\
\hline Farm price & L.E/Ardabs & 425.00 & 425.00 & 425.00 \\
\hline Total revenue & L.E/Fadden & 7903.73 & 9005.75 & 9532.75 \\
\hline Total costs & L.E/Fadden & 6584.24 & 7243.20 & 7716.26 \\
\hline Average total costs & L.E/Ardabs & 354.05 & 341.82 & 344.02 \\
\hline Net Profit & L.E/Fadden & 1319.48 & 1762.55 & 1816.49 \\
\hline Net Profit & L.E/Ardabs & 70.95 & 83.18 & 80.98 \\
\hline Revenue loss & L.E/Fadden & 0.00 & 1102.03 & 1629.03 \\
\hline Profit loss & L.E/Fadden & 0.00 & 443.07 & 497.00 \\
\hline $\begin{array}{c}\text { Profit loss in Sharkia } \\
\text { governorate }\end{array}$ & Million L.E & 0.00 & 191.60 & 214.92 \\
\hline Profit loss in Egypt & Million L.E & 0.00 & 1496.68 & 1678.88 \\
\hline
\end{tabular}

Source : collected and calculated from a sample survey data in 2015.

\subsubsection{At the middle of masqa}

By applied the probabilistic model on data of sample under study to measure the average of actual wheat production and the cost of its unit, so that quantity of wheat production and profit loss of wheat producers at middle of masqa of sample study are presented in table (6), showed the following results: 
- The average of farm price per ardab of wheat production at middle of masqa was estimated about $425 \mathrm{~L} . \mathrm{E} / \mathrm{ardab}$. Also the average of the actual wheat production per fadden of wheat production was about $19.19 \mathrm{ardab} /$ fadden. In addition average total cost of wheat production at middle of masqa was estimated to be 358.91 L.E/ardab (6885.74 L.E/fadden). Total revenue of actual wheat production was 7731.18 L.E/fadden. Net profit of actual wheat production at middle of masqa was about 1267.88 L.E/fadden.

- Optimum wheat production at middle of masqa was amounted about 20.21 ardab/fadden and its average total cost was estimated at 350.79 L.E/ardab (7075.82 L.E/fadden). According the previous, total revenue of optimum wheat production was $8551 \mathrm{~L} . \mathrm{E} /$ fadden. Net profit loss of actual wheat production at middle of masqa was about 397.38 L.E/fadden.

- Quantity of wheat production maximizing profit (Economic production) at middle of masqa was about $20.71 \mathrm{ardab} /$ fadden. Average total cost of economic production level at middle of masqa was estimated at 351.89 L.E/ardab (7287.55 L.E/fadden). Total revenue was amounted to be $8801.75 \mathrm{~L}$.E/fadden. Net profit loss estimated to be $648.13 \mathrm{~L}$.E/fadden because the actual production level cannot be reached to economic production level that maximized profit at middle of masqa, and that means the inefficient use of productive resources by wheat producers in the sample.

- Total costs of wheat production, average total cost and total revenue and net profit were differentiated from production level to another, so that net profit per ardab of wheat at level of optimum production was achieved to the most value that estimated about 74.21 L.E/ardab. Next production level that maximized profit was amounted to be $73.11 \mathrm{~L} . \mathrm{E} / \mathrm{ardab}$. Level of actual production was reached to the least value that estimated about $66.09 \mathrm{~L}$.E/ardab. Net profit per ardab of wheat at actual production level was represented about $87.7 \%$ and $89.37 \%$ to both optimum and economic production, respectively.

- Because of not produced the level of optimum wheat production so that net profit loss was amounted to be 97.42 million L.E of area over Sharkia governorate, and about 761.05 million L.E of area over Egypt. Also, because of not produced the level of wheat economic production ( maximizing profit) so that net profit loss was amounted to be estimated at 106.52 million L.E of area over Sharkia governorate, and about 832.06 million L.E of area over Egypt.

Table ( 6 ) : Quantity of wheat production and profit loss of wheat producers at middle of Masqa of sample study.

\begin{tabular}{|c|c|c|c|c|}
\hline Item & Unit & $\begin{array}{c}\text { Actual } \\
\text { production }\end{array}$ & $\begin{array}{c}\text { Optimum } \\
\text { production }\end{array}$ & $\begin{array}{c}\text { Economic } \\
\text { Production }\end{array}$ \\
\hline Quantity of production & Ardabs/Fadden & 19.19 & 20.12 & 20.71 \\
\hline Farm price & L.E/Ardabs & 425.00 & 425.00 & 425.00 \\
\hline Total revenue & L.E/Fadden & 8153.63 & 8551.00 & 8801.75 \\
\hline Total costs & L.E/Fadden & 6885.74 & 7057.82 & 7287.55 \\
\hline Average total costs & L.E/ Ardabs & 358.91 & 350.79 & 351.89 \\
\hline Net Profit & L.E/Fadden & 1267.88 & 1493.18 & 1514.20 \\
\hline Net Profit & L.E/ Ardabs & 66.09 & 74.21 & 73.11 \\
\hline Revenue loss & L.E/Fadden & 0.00 & 397.38 & 648.13 \\
\hline Profit loss & L.E/Fadden & 0.00 & 225.29 & 246.32 \\
\hline $\begin{array}{c}\text { Profit loss in Sharkia } \\
\text { governorate }\end{array}$ & Million L.E & 0.00 & 97.42 & 106.52 \\
\hline Profit loss in Egypt & Million L.E & 0.00 & 761.05 & 832.06 \\
\hline
\end{tabular}

Source : collected and calculated from a sample survey data in 2015. 


\subsubsection{At the end of masqa}

By applied the probabilistic model on data of sample under study to measure the average of actual wheat production and the cost of its unit, , so that quantity of wheat production and profit loss of wheat producers at END of masqa of sample study are presented in table (7), showed the following results:

- The average of farm price per ardab of wheat production at end of masqa was estimated about $425 \mathrm{~L}$.E/ardab. Average of the actual wheat production per fadden of wheat production was about $16.73 \mathrm{ardab} /$ fadden. Average total cost of wheat production at end of masqa was estimated to be 378.03 L.E/ardab (6322.91 L.E/fadden). Total revenue of actual wheat production was 7108.55 L.E/fadden, and net profit of actual wheat production at end of masqa was about 785.64 L.E/fadden.

- Optimum wheat production at end of masqa was amounted about 22.54 ardab/fadden and its average total cost was estimated at 366.7 L.E/ardab (7589.27 L.E/fadden). Total revenue of optimum wheat production was 9579.5 L.E/fadden. Net profit loss of actual wheat production at end of masqa was about 1204.58 L.E/fadden.

- Quantity of wheat production maximizing profit (economic production) at end of masqa was about $24.03 \mathrm{ardab} /$ fadden. Average total cost of economic production level at end of masqa was estimated at 339.44 L.E/ardab (8156.81 L.E/fadden). Total revenue was amounted to be 10212.75 L.E/fadden. Net profit loss estimated to be $1270.29 \mathrm{~L} . \mathrm{E} /$ fadden because the actual production level cannot be reached to economic production level that maximized profit at end of masqa, and that means the inefficient use of productive resources by wheat producers in the sample.

Table ( 7 ) : Quantity of wheat production and profit loss of wheat producers at end (tail) of Masqa of sample study.

\begin{tabular}{|c|c|c|c|c|}
\hline Item & Unit & $\begin{array}{c}\text { Actual } \\
\text { production }\end{array}$ & $\begin{array}{c}\text { Optimum } \\
\text { production }\end{array}$ & $\begin{array}{c}\text { Economic } \\
\text { Production }\end{array}$ \\
\hline Quantity of production & Ardabs/Fadden & 16.73 & 22.54 & 24.03 \\
\hline Farm price & L.E/Ardabs & 425.00 & 425.00 & 425.00 \\
\hline Total revenue & L.E/Fadden & 7108.55 & 9579.50 & 10212.75 \\
\hline Total costs & L.E/Fadden & 6322.91 & 7589.27 & 8156.81 \\
\hline Average total costs & L.E/Ardabs & 378.03 & 336.70 & 339.44 \\
\hline Net Profit & L.E/Fadden & 785.64 & 1990.23 & 2055.94 \\
\hline Net Profit & L.E/Ardabs & 46.97 & 88.30 & 85.56 \\
\hline Revenue loss & L.E/Fadden & 0.00 & 2470.95 & 3104.20 \\
\hline Profit loss & L.E/Fadden & 0.00 & 1204.58 & 1270.29 \\
\hline $\begin{array}{c}\text { Profit loss in Sharkia } \\
\text { governorate }\end{array}$ & Million L.E & 0.00 & 520.90 & 549.31 \\
\hline Profit loss in Egypt & Million L.E & 0.00 & 4069.08 & 4291.05 \\
\hline
\end{tabular}

Source : collected and calculated from a sample survey data in 2015.

- Average total cost, total revenue and net profit were differentiated from production level to another, so that net profit per ardab of wheat at level of optimum production was achieved to the most value that estimated about $88.3 \mathrm{~L}$.E/ardab. Next production level that maximized profit was amounted to be 85.56 L.E/ardab. Level of actual production was reached to the least value that estimated about 46.97 L.E/ardab. Net profit per ardab of wheat at actual production level was represented about $12.02 \%$ and $17.85 \%$ to both optimum and economic production, respectively. 
- Because of not produced the level of optimum wheat production so that net profit loss was amounted to be 520.9 million L.E of area over Sharkia governorate, and about 4069.08 million L.E of area over Egypt. Also, because of not produced the level of wheat economic production ( maximizing profit) so that net profit loss was amounted to be estimated at 549.31 million L.E of area over Sharkia governorate, and about 4291.05 million L.E of area over Egypt.

\section{Summary and Conclusion}

Agriculture is the largest component of the water demand in Egypt, as it consumes more than $85 \%$ of Egypt's share of Nile water annually. This study is concentrated on the creation of water users associations is justified by the participatory approach in water management to allow farmers to concentrate efficiently their efforts and means for joint actions aimed at the optimum utilization of water resources on irrigated and reclaimed lands as well as it is focused also on the impact of the site in distribution of water along the Masqa and reduce differences in water size distributed, so that to accomplish the objectives of this study a questionnaire sheets has been designed to collect and conduct a suitable primary field data applied on a random intentional sample Sharkia governorate in Faqous and Abou-Hamad because the majority of water links exist in these two centers. The study used both quantitative and descriptive analysis represented in using the total cost approach and the average cost approach to measure the impact of the farm location at the masqa on the levels of optimum and actual productivity and also on maximizing profit of wheat production. To find out the impact of the location in distribution of water along the Masqa and reduce differences and disparities in distributed water volume so 160 producers of wheat crop has been divided along Masqa the into three groups based on their site along Masqa as follow : (a)At the head ( 1 st group). (b) At the middle ( 2 nd group). (c) At the end (3rd group). The most important results can be summarized by applied the probabilistic model on data of sample under study of wheat producers as follow:

- Average of the actual wheat production per fadden of wheat production along masqa was about 18.19 ardab/fadden. But optimum wheat production was amounted about 20.87 ardab/fadden and quantity of wheat production maximizing profit (economic production) was about 21.91 ardab/fadden. Because of not produced the level of optimum wheat production so that net profit loss was amounted to be 216.48 million L.E of area over Sharkia governorate, and about 1691.11 million L.E of area over Egypt. Also, because of not produced the level of wheat economic production ( maximizing profit) so that net profit loss was amounted to be estimated at 234.73 million L.E of area over Sharkia governorate, and about 1833.67 million L.E of area over Egypt.

- Average of the actual wheat production per fadden at head of masqa was about 18.6 ardab/fadden. Also optimum wheat production was amounted about 21.19 ardab/fadden and quantity of wheat production maximizing profit (economic production) was about $22.43 \mathrm{ardab} /$ fadden. Because of not produced the level of optimum wheat production so that net profit loss was amounted to be 191.6 million L.E of area over Sharkia governorate, and about 1496.68 million L.E of area 
over Egypt. Also, because of not produced the level of wheat economic production (maximizing profit) so that net profit loss was amounted to be estimated at 214.92 million L.E of area over Sharkia governorate, and about 1678.88 million L.E of area over Egypt.

- Average of the actual wheat production per fadden at middle of masqa was about $19.19 \mathrm{ardab} /$ fadden. In addition optimum wheat production was amounted about $20.21 \mathrm{ardab} /$ fadden and quantity of wheat production maximizing profit (economic production) was about $20.71 \mathrm{ardab} /$ fadden. Because of not produced the level of optimum wheat production so that net profit loss was amounted to be 97.42 million L.E of area over Sharkia governorate, and about 761.05 million L.E of area over Egypt. Also, because of not produced the level of wheat economic production ( maximizing profit) so that net profit loss was amounted to be estimated at 106.52 million L.E of area over Sharkia governorate, and about 832.06 million L.E of area over Egypt.

- Average of the actual wheat production per fadden at end of masqa was about 16.73 ardab/fadden. Also optimum wheat production was amounted about 22.54 ardab/fadden and quantity of wheat production maximizing profit (economic production) was about $24.03 \mathrm{ardab} /$ fadden. Because of not produced the level of optimum wheat production so that net profit loss was amounted to be 520.9 million L.E of area over Sharkia governorate, and about 4069.08 million L.E of area over Egypt. Also, because of not produced the level of wheat economic production (maximizing profit) so that net profit loss was amounted to be estimated at 549.31 million L.E of area over Sharkia governorate, and about 4291.05 million L.E of area over Egypt.

\section{Recommendations}

- Apply optimum combination of wheat crop production all over Sharkia Governorate and the Arab Republic of Egypt to increase total net income for the farmer and agricultural sector .

- Because of limited agricultural land, limited water, population increasing and to reduce the food gap of wheat crop, it should trend towards vertical expansion of production through the use of modern technology and improved varieties to reduce costs and increase the net revenue per fadden .

- Expansion of studies conduct to modern agricultural techniques and access to effective recommendations that provide quantities of water for irrigation, seeds and increase agricultural production.

\section{References}

- Agriculture directorate Sharkia governorate, Management of the Agricultural Statistics Department, unpublished data, 2014.

- Heady,E.O. and Dillon,L. , Agricultural Production Economics, Lowa state university press, Ames,Lowa, 1966.

- Ministry of Agriculture and Land Reclamation, Economic Affairs Sector, Central Administration of Agricultural Economics, Agricultural Economics Bulletin, various issues. 


\section{Location on Salted land at Sharkia Governorate}

- Mosherr.AT., Getting agriculture moving. Fredrick A. Praeger publisher New York, 1966.

- Patel .N.T. , Inputs productivity in agriculture. Mohan primlani for Oxford and IBH publishing co, Delhi, 1982.

- Shafek, Dina. An economic study for modern agricultural technologies in Sharkia governorate. PHD thesis, Department of agricultural economics, Faculty of agriculture, Zagazig university,2015.

\section{روابط مستخدمي المياه : تأثير موقع المزرعة علي الأراضي المالحة بمحافظة الثرقية

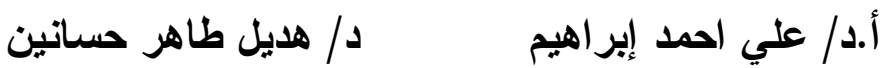 قسم الاقتصاد الززاعي ، كلية الزراعة ، جامعة الزقازيق ، مصر فير فير}

الملخص

يعتبر نهر النيل هو المصدر التقليدي الرئيسي في مصر للمياه العذبة والمخزنة فـي بحيـرة ناصــر لتلبية احتياجاتها المائية وذلك من خلال حصة مصر السنوية من المياه ، و الذي تقدر بحــو الي 00,0 مليــار متز مكعب ، وفي ظل ندرة مياه الامطار فضلا عن السياسات الحكومية لاستصلاح المزيد مــن الأر اضــي وتشجيع القطاع الصناعي بشكل مستمر، إلا ان تلك الموارد المائية تو اجه العديد من التحديات اهمها محدودية القدر المتاح من المياه فضلا عن تحرير التركيب المحصولي الذي جعل من الصعب التكهن بمــا يمكـنـ ان تحتاجه المحاصيل من المياه ونظر ا لان الزراع يعملو ابنظام يتولى فيه المشاركين فـي المجـــى المــائي

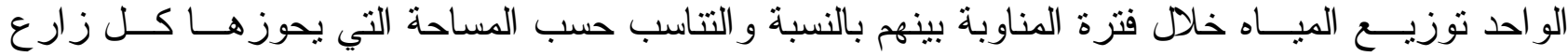
كولكن موقع المزرعه على طول المسقى ذو تأثير واضح على كفاءة استخدام المــورد المــائى. فــالمز ارع الو اقعة فى بداية المسقى غالبا ما تلجأ إلى الاستخدام الز ائد لمورد المباه نتيجة لوفرة مياه الرى عنـــد بــدايات المساقى. و على العكس من ذللك فالمز ارع الو اقعة فى نهاية المسقى غالباً ما تعانى من نقــص و اضــــح فـى إمدادات مياه الرى وبصفة خاصة فى الموسم الصيفى. وفى كلا الحالتين يؤدى الاستخدام الز ائــــ للميــاه أو النقص الواضح فى إمدادات المباه إلى تتاقص الإنتاجيه الفعلية عن الإنتاجية المتوسطة لذلك ركز البحث الـي القاء الضوء علي روابط مستخدمي المياه و أهميتها في تحقيق العدالة في توزيع المياه بين المزارعين حتـي يتمكن المزارعين التي تقع أر اضيهم في نهايات الترع من الحصول علي المياه اللازمة لري محاصيلهم فضلا

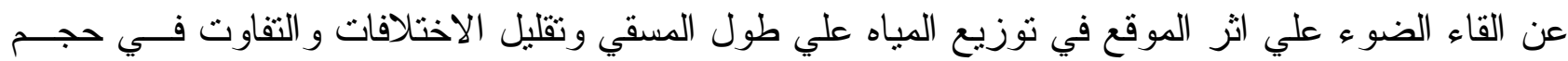
المياه الموزعة ،لذلك اعتمدت الدر اسة علي البيانات الثانوية المنشورة وغير المنشورة مــن وزارة الزر اعــة

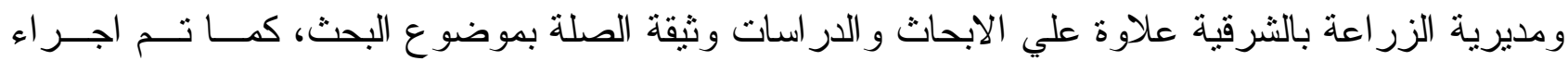
در اسة ميدانية بمحافظة الثرقية جمعت من مركزي فاقوس و ابو حماد نظر التو اجد اكبر روابط لمسستخدمي المياه في هذين المركزين ، من خلال استمارة استبيان صمدت خصيصـا لهذا الغرض وتم تجميعها بالمقابلـــة الثخصية خلال شهر مارس 10 ـ. ب. 